\title{
THERAPEUTIC COMMUNICATIONS PHASE IN CHILDREN DOWN SYNDROM: CASE STUDY IN BANTUL, YOGYAKARTA.
}

\author{
Suciati $^{1}$, Adhea Rifty ${ }^{2}$ \\ Universitas Muhammadiyah Yogyakarta \\ Email: suciati@umy.ac.id
}

\begin{abstract}
ABSTRAK
Komunikasi terapeutik adalah upaya penyembuhan melalui komunikasi. Pada kasus terapi anak Down Syndrome, terapis dituntut untuk memperhatikan faktor-faktor yang mempengaruhi pelaksanaan terapi agar komunikasi terlaksana secara efektif sehingga tujuan penyembuhan dapat tercapai. Anak dengan Down Syndrome memerlukan perhatian khusus karena biasanya mereka mengalami keterlambatan perkembangan dan masalah perilaku yang mempengaruhi komunikasi dan interaksi sosial. Penelitian ini bertujuan untuk mendeskripsikan fase komunikasi terapeutik terapis dengan anak down syndrome dalam membentuk kemandirian di SLBN 1 Bantul Yogyakarta. Penelitian ini menggunakan tipe deskriptif kualitatif dengan 2 (dua) pasang informan yaitu PT dan LN. Data diperoleh melalui wawancara, observasi, dan dokumentasi. Berdasarkan hasil penelitian dapat disimpulkan bahwa terdapat empat fase komunikasi terapeutik yaitu fase pra interaksi, fase orientasi, fase kerja, dan fase terminasi. Dalam fase kerja, terapis menggunakan YouTube dalam terapi bermain. Penggunaan media baru ini telah terbukti dapat meningkatkan mood anak dan mempercepat penyembuhan. Keempat fase komunikasi terapeutik tersebut telah dilakukan secara efektif oleh informan terapis dan terbukti bahwa anak down syndrome dapat mengalami perubahan ke arah penyembuhan dalam meningkatkan kemandirian, berinteraksi, dan membangun sikap peduli. Informan lainnya kurang maksimal melaksanakan keempat fase komunikasi terapeutik tersebut sehingga menyebabkan anak menjadi malas bersekolah dan lambat berkembang ke arah yang lebih baik.
\end{abstract}

Kata Kunci: Komunikasi Terapeutik, Fase Pra-Interaksi, Fase Orientasi, Fase Kerja, Fase Terminasi

\section{THERAPEUTIC COMMUNICATIONS PHASE IN CHILDREN DOWN SYNDROM: CASE STUDY IN BANTUL, YOGYAKARTA.}

\begin{abstract}
Therapeutic communication is an attempt at healing through communication. In the case of Down Syndrome child therapy, therapists are required to pay attention to factors that influence the implementation of therapy so that communication is carried out effectively so that healing goals can be achieved. Children with Down syndrome require special attention because they usually experience developmental delays and behavioral problems that affect communication and social interaction. This study intends to describe the therapeutic communication phase of therapists with children with Down syndrome in forming independence in SLBN 1 Bantul, Yogyakarta. This study uses a qualitative descriptive type with 2 (two) pairs of informants, PT and LN. Data obtained through interviews, observations, and documentation. Based on the results of the study, it can be concluded that there are four therapeutic communication phases which include the pre-interaction phase, the orientation phase, the work phase, and the termination phase. In the work phase, the therapist uses YouTube in play therapy. The use of this new media has been proven to improve children's moods and thus speed healing. The four phases of therapeutic communication have been carried out effectively by a therapist informant and it is proven that children with down syndrome can experience changes toward healing in increasing independence, interacting, and building caring attitudes. The other informants did not carry out the four phases of therapeutic communication to the maximum, causing children to be lazy to attend school and slow to develop towards a better direction.
\end{abstract}

Keywords: Therapeutic Communication, Pre-Interaction Phase, Orientation Phase, Work Phase, Termination Phase 
Korespondensi: Suciati, Adhea Rifty S.I.Kom. Universitas Muhammadiyah Yogyakarta. Jl. K.H. Mas Mansyur, Kav 35, Jakarta Pusat, Indonesia, 10220. No. Hp/Whatsapp: 083843617988. Email: suciati@umy.ac.id

\section{PRELIMINARY}

The principles of interpersonal communication are used fully in the therapeutic communication process, such as openness, positive attitude, supportive attitude, equality, and empaty. In its implementation in the world of education, the model of teaching children with Down syndrome cannot be compared to the teaching model with other special needs. Although Down syndrome is a child with special needs, but they have the potential to be developed. Even children with special needs have more potential that can be developed if there is guidance, direction and education such as therapy that will be provided for them. Children with Down syndrome require special attention because they usually experience developmental delays and behavioral problems. They are slow in language development, speak difficult to understand, there is no understanding of the dangers or not of an action, making problems to seek attention, obsessive, stubborn, easy tantrum, thus affecting communication and social interaction (http://terapianak.com, Februari 2019).

Some of the characteristics of children with down Syndrome include: First, they have the same physiological, social and emotional basis as children who do not have intellectual disabilities. Second, they are always external locus of control so that they can make mistakes (expectancy for filure). Third, children with Down syndrome imitate the correct behavior of others in an effort to overcome the mistakes that the child might do (outerdirectedness). Fourth, having behavior that is not independent or cannot regulate itself. Fifth, have problems relating to social behavior (social behavior) and problems related to the characteristics of learning. Sixth, there are problems in language and pronunciation and problems in physical health. Seventh, it has abnormalities in sensory and motion as well as psychiatric-related problems in the form of depressive symptoms (Khairun Nida, 2013). Therapy in children with Down syndrome refers more to how children can live with better health and can interact and not depend on others / independently. Independence is a process of growth and development of the attitude of someone who was born from the heart to learn to organize yourself. Growing means growing in all things or the process of maturing a child who adheres to his own principles, not dependent on others (Harini, and Hawani: 2003).

Children with Down Syndrome who are treated are expected to experience advancement in their abilities, both physical and mental. To achieve progress in terms of these abilities, professional therapists are needed. The profession really requires patience and accuracy in its implementation and is an educated person in their field. A professional therapist is also challenged to understand the child so as not to affect the child's mood when doing healing therapy. The therapist must always be ready to express emotional feelings in healing. Obstacles in the process of therapy must be overcome. 
A teacher at SLB who is also a therapist must have more knowledge about therapeutic methods according to the child's needs. On the other hand, the family is also the main educator for children with Down syndrome and is part of the people they trust. So that sometimes the family becomes a factor for children to be independent and dependent, therefore parents will choose to carry out therapy to children in order to change. Extraordinary Schools (SLB) are more often chosen by parents of children with Down syndrome because they think that the place has competent, experienced teaching staff and sufficient facilities. Thus not only mastery of the material is a requirement for SLB teachers, but also a different and trained approach when they teach children.

In the message inserted in "Dear Future Mom", one of the anxiety of parents of children with Down syndrome is related to the education that will be given to him. Some parents choose to place their children in special schools. The school also teaches them how to communicate with others, through predetermined phases. Therefore, researchers will discuss the phases (https://tirto.id/memilihpendidikan-untuk-anak-down-syndrome-cGun,

Februari 2019) that therapists run in shaping the independence of children with Down syndrome. The research location chosen was SLBN 1 Bantul, Yogyakarta.

In a study needed support from the results of research ever conducted relating to research on therapeutic communication of children with Down syndrome. According to research from O PopaVelea and VL Purcarea with the title Issues of therapeutic communication relevant for improving quality of care that the integration of communication training in the care model is used as a good tool for therapeutic communication used as a valuable future approach to obtain more results good in the field of therapy. Therapeutic communication is a tool for the healing process that must use training so that the maximum in the healing process in children with Down syndrome (Valea and Purcarea, 2014). Therapeutic communication training in long-term care institutions: Recommendations for future research written by Lene Levy-Storms in 2008, states that the following therapeutic communication techniques can be taught and can benefit the quality of life of staff and adults: verbal and noncommunication behaviors Verbals include open questions, positive statements, eye contact, affective touches, and smiles. (Storms, Lene Levy, 2008).

The Use of Therapeutic Communication Symbol to Motivate Patient's Healing written by Zainun, et al. in 2017 stated that therapeutic communication activities carried out by health workers to patients carried out in the form of communication with warmth and sincerity. Communication activities can reduce the burden of mental disorders patients. In the theory of psychological therapy can be done by someone with being open to convey problems to others (Zainun, et all: 2007). The Use of Metaphors in the Service of the Therapeutic Alliance and Therapeutic Communication written by John J. Stine in 2005 states that the use of metaphors as conceptual and clinical tools in treatment situations can enhance therapeutic alliances and strengthen 
the effectiveness of therapeutic communication (Stine: 2005). The effect of the planned therapeutic communication program on therapeutic communication skills of pediatric nurses written by Jaklein R. et al. 2015 states that therapeutic communication is the basis of an interactive relationship between the health team and their patients that provides opportunities to build relationships, understand client experiences, formulate individual or client interventions and optimize health care resources (Younis, 2015).

The purpose of this study is to describe the therapeutic communication phase of the teaching of children with Down syndrome in SLBN 1 Bantul. In this study also described inhibiting factors and supporting factors of the therapeutic communication process conducted by the teacher. The research is also expected to be able to contribute to the development of science, especially effective therapists for children with Down syndrome. As for practically, this research will be expected to be an evaluation guide for schools in conducting the therapeutic phase with better use of new media. For teachers, the results of this study can be a reference to minimize the inhibiting factors of therapy so that the healing process can run effectively and efficiently.

\section{RESEARCH METHODS}

In this study using a qualitative descriptive type, the researcher makes a complex picture, examines words, detailed reports from the respondents' views, and conducts studies in natural situations (Creswell, 2010). With descriptive research the researcher tries to describe an event that is used as the center of attention by not giving special treatment to the event (Juliansyah, 2011). In this study, the authors intend to describe the use of YouTube in the process / therapeutic communication phases of therapists to children with Down syndrome in SLBN 1 Bantul, Special Region of Yogyakarta.

To get complete, accurate, and accountable data, the authors use interview, observation, and documentation data collection techniques. This study uses a snowball sampling informant technique. This technique is a sampling where the researcher does not know the parties who have enough information. Researchers began by meeting with the principal who was certain to be able to appoint experienced teachers who were able to answer research questions about the use of YouTube media in the treatment of Down syndrome children. The interview process with the informant will stop when the answers from the informants are at the saturation point or show similarity with one another (Sugiyono, 2010).

The measurement of the validity of the data is based on triangulation techniques. Triangulation is a technique of checking the validity of data which also utilizes something different. There are several types of triangulation, namely source triangulation, method triangulation, researcher triangulation, and theory triangulation. This research uses source triangulation technique, meaning that all data checking in various sources / more than one informant. The informants in question are SLBN 1 Bantul teachers. Based on data obtained through interviews with teachers and observations of students, categorization and description are carried 
out. The next step, the data is analyzed which will produce conclusions.

\section{RESULTS AND DISCUSSION}

The informants of this research are the teachers who also act as therapists. Teachers will try to communicate with children so that children feel comfortable so that the communication process can run smoothly. When the teacher feels that the child feels comfortable, it is easier for him to communicate with the child so that the problems experienced by the Down Syndrome child can achieve independence.

\section{Pre-interaction phase}

The pre-interaction phase is the preparation period before contacting and communicating with pediatric patients with Down syndrome. In this phase, the therapist explores feelings by identifying their strengths and weaknesses (Untung. S and Tatik , 2003). At this stage the therapist also looks for the patient's information as opposed to speaking. The information is obtained by the teacher by collecting data about children. Teachers can ask parents and previous teachers who have dealt with children about this problem. Other information is the ability of the child and the talents he has mastered, and explore children's feelings. This is useful to reduce obstacles in conducting therapeutic communication to children by exploring the feelings that exist in children (Aziz Alimul, 2005). At this stage the therapist also looks for the patient's information as opposed to speaking. The information is obtained by the teacher by collecting data about children. Teachers can ask parents and previous teachers who have a deal with children about this problem. Other information is the ability of the child and the talents he has mastered, and explore children's feelings. This is useful to reduce obstacles in conducting therapeutic communication to children by exploring the feelings that exist in children.

At this stage the therapist also looks for the patient's information as opposed to speaking. The information is obtained by the teacher by collecting data about children. Teachers can ask parents and previous teachers who have a deal with children about this problem. Other information is the ability of the child and the talents he has mastered, and explore children's feelings. This is useful to reduce obstacles in conducting therapeutic communication to children by exploring the feelings that exist in children (Rakhmat, 1988). To get closer to the child, the thing done by PT is to give attention to attract the child's interest by providing movements that provoke the child's stimulus. Attention such as being friendly, spreading smiles, talking modestly to children, even being sincere is part of the attention given by PT to children with Down syndrome. In contrast to $\mathrm{LN}$, he found children with Down Syndrome who were very passive so it was difficult to communicate with. But he digs information, by finding out about children by asking him to chat.

\section{Orientation Phase}

The orientation / introduction phase is carried out every time a patient is met. The goal in this stage is to validate the accuracy of the data and plans that have been made according to the patient's current situation, and evaluate the results of past actions. At this stage the instructor is encouraged to give greetings and smiles to the client, and 
introduce names. It aims to always have someone pay attention to their needs, explain the activities carried out, explain the time needed to carry out activities and call the child in accordance with his nickname (Aziz Alimul, 2005).

The initial greeting can be categorized as a psychological approach to communication and it can be applied to children with Down syndrome. Psychology sees communication as being initiated by inputting into our sense organs in the form of data. The stimulus can be in the form of people, messages, and sounds. Even initial sayings such as "hi, how are you" are stimuli in the form of sights, sounds, and so on. This has been done by PT where he will always greet the child when doing the therapy process. This he did to provoke children to respond and is usually also followed by giving simple questions.

Then the expressions that PT usually gives to clients are smiles, jokes and doing interesting things to show a cheerful initial impression. When the therapist does this and the child begins to want to respond, the feeling grows that he starts intense with the child and feels a good relationship between the therapist and the Down syndrome child so as to form an attitude of mutual trust. When you want to call a child, LN does physical touch, because basically every child with Down syndrome has different characteristics. A good step if you do physical touch when doing therapy to children with passive Down Syndrome. The physical touch can be cares. People who are caressed will feel cared for, loved, and valued (Zulfan, and Sri Wahyuni, 2012). The usual chat when meeting is also conducted by the LN with clients in the orientation phase. Especially the case of LN with the client is very different because the client is very passive. In fact, he never gave any expression so he could not be invited to communicate at all. Therefore $\mathrm{LN}$ is actively communicating. At this stage of orientation he acts mediocre and rarely communicates with clients.

\section{Work Phase}

This phase will dissect based on what is discovered by the teacher in the initial phase of the child. There are efforts being made in order to increase independence, develop talents, make children able to interact and foster mutual assistance. This work phase is the most important stage in achieving the final goal (Aziz Alimul: 2005). At this stage the treatment of children differs according to their character. Achievement of the goals of interaction and independence is done through improving children's cognitive, sensory and motor skills. These stimuli can take the form of learning while playing. Learning activities while playing in children with Down syndrome will implement communicating with nature, understanding the environment by building sensitivity in children and learning about the environment.

In addition to playing methods, PT also utilize communication technology such as YouTube. The use of appropriate technology can help improve the quality of healing of children, for example by utilizing social media such as YouTube. Watching on YouTube is considered as a therapy that is done while playing so that children stay happy in enjoying the periods of therapy. The use of appropriate technology can improve the quality of 
nursing care to clients. That is because technological development has been proven to affect the implementation of each stage when implementing therapy, especially in children with Down syndrome. Healing for children is done by showing education-education that stimulates children's stimuli such as seeing people dancing and singing. Dance itself becomes an alternative therapy for sufferers of Down syndrome because their love to move the body accompanied by music can be one way to maintain mood while increasing their motor skills and concentration. If taken seriously, becoming a dancer can be one of the promising professions so that they can be more independent

(https://www.kenangan.com/ceritainspirasi/namira -zania-diantara-down-syndrome-tari-danmodelling, Januari 2020).

Play therapy with YouTube media was also conducted by PT. He presents ablutions on youtube, so that children are able to remember and imitate limb movements. By watching, the child's mood during the therapy process becomes good. Likewise, training with simple things such as putting his belongings in a bag, taking his own food, the informant will find an appropriate show. The mimicking process accompanied by a good mood will speed up the healing process. When a child has a bad mood, the teacher will communicate smoothly and make physical touch and suggest the child to play if he wants. The LN, who usually strokes the child's shoulders when asking for help or asking the child to do something.

Non-verbal communication is always carried out by LN such as movement, smile, physical touch. Nonverbal communication has a greater impact than verbal communication. Stuart and Sundeen say that about $7 \%$ of understanding can be caused by words, $30 \%$ due to paralinguistic language and $55 \%$ due to body language (Damayanti, 2008).

\section{Termination Phase}

This phase explains whether the child will continue the therapeutic process he is running or even wants to end it. Activities that can be done are concluding the results and the process, planning follow-up with the child's parents and continuing the contract (Damayanti, 2008). The results of the study found that the therapeutic process of the two teachers, PT and LN, would continue until the child's education had truly ended. The decision to continue therapy at school must be agreed by the child's parents.

So in essence the teacher conducts therapeutic communication to the child by looking at the condition of the child to be dealt with. Although the teacher runs the therapeutic communication to children with Down syndrome sincerely, the status and role of the teacher when communicating influences the therapeutic communication process and influences the child's development to recover (Rati, 2015). Factors that influence differences in the healing of children in addition to the different character of children, the way teachers do therapy is also the reason. Teachers who are more friendly, humble, diligent in chatting with children and always use movements when communicating will be considered attractive by children with Down syndrome because children like them sometimes do not understand if just verbal communication is 
carried out, they will also feel comfortable if the teacher makes physical touch when want to do 'something' and the teacher's attitude during therapy is very influential. The role of the media in this case can be an alternative in improving the child's mood so that it is not passive.

\section{CONCLUSION}

The role of the teacher in therapeutic communication is as a helper who helps children to recover in a better direction. In the pre-interaction phase, which is the initial phase, the teacher will first dig up information about the child by asking the teacher beforehand and the child's parents. But one of the informants, LN, did not look for information about children but instead perceived themselves about the condition of the child. When in the orientation phase which is an introduction phase, instructors are encouraged to give greetings and spread smiles to children and introduce themselves. However, LN only communicate improperly to children with Down syndrome because they assume that children with Down syndrome who are handled are very passive so that they will not respond.The work phase is the dissecting phase based on the results found by the teacher. Teachers are required to provide healing to children both in forming independence and honing children's abilities by inviting children to chat to get responses and invite children to learn while playing. To foster a child's mood, the teacher invites children to watch shows to improve cognitive, sensory, and motor skills. Based on these shows, children are trained to imitate the movements of people dancing, singing, and performing ablution. With the ability to remember to improve, children will be able to imitate it in everyday life.The termination phase is the last phase of the entire therapy process of Down syndrome children. In this phase the two informants stated that the therapy process would continue. Children are required to continue to get the therapy process until the end of school level. Every child must be treated differently according to his character. When each phase is run well there will be a change in the child in an effort towards independence. But if the healing is not in accordance with the phases that have been described then the child will be difficult to develop and the child will be lazy to carry out the therapy process.

\section{BIBLIOGRAPHY}

Aziz Alimul, Hidayat. 2005. Pengantar Ilmu Keperawatan Anak 1. Jakarta: Penerbit Salemba Medika.

Creswell, John W. 2010. Research Design Pendekatan Kualitatif, Kuantitatif, dan Mixed. Yogyakarta: Pustaka Pelajar

Damayanti, Mukhripah, 2008. Komunikasi Terapeutik dalam Praktik Keperawatan. Bandung: Refika Aditama.

Khoirun Nida, Fatma Laili Juli - Desember 2013. Komunikasi Bagi Anak Berkebutuhan Khusus. Volume 1, Nomor 2, hal 170-171 (diakses pada tanggal 14 Desember 2019 pukul 08.15 WIB).

Harini, Sri, and Al-Halwani , Aba Firdaus. 2003. Mendidik Anak Sejak Dini. Yogyakarta: Kreasi Wacana.

Juliansyah, Noor. 2011. Metodologi Penelitian. Jakarta: Prenada Media Group

Rakhmat, Jalaluddin. 1988. Psikologi Komunikasi edisi revisi kedua. Bandung: PT Remaja Rosdakarya.

Sugiyono. 2010. Metode Penelitian Pendidikan Pendekatan Kuantitatif, kualitatif, dan R\&D. Bandung: Alfabeta. 
Untung,S. Christina,L. I, \& Tatik I. 2003. Komunikasi Kebidanan. Jakarta:EGC.

Zulfan, Saam, dan Sri Wahyuni. 2012. Psikologi Keperawatan. Jakarta: PT Raja Grafindo Persada. Internet:http://terapianak.com/pengertian-downsyndrome/ 26 Februari 2019 at 20.45 WIB https://tirto.id/memilih-pendidikan-untuk-anakdown-syndrome-cGun 26 Februari 2019 at 21.57 https://www.kenangan.com/ceritainspirasi/namira -zania-diantara-down-syndrome-tari-danmodelling, Januari 2020

Younis, Jaklein R. et all. 2015. Effect of the planned therapeutic communication program on therapeutic communication skills of pediatric nurses. Journal of Nursing Education and Practice. Menoufiya University, Menoufiya, Egypt, , Benha University, Benha, Egypt. Vol. 5 No. 8 (20 Januari 2020 at 11.22)

Stine, John J. 2005. The Use of Metaphors in the Service of the Therapeutic Alliance and Therapeutic Communication. The Journal of the American Academy of Psychoanalysis and Dynamic Psychiatry: Vol. 33, No. 3, pp. 531-545 (22 Januari 2020 at 7.41)

Stroms, Lene Levy 2008. Therapeutic communication training in long-term care institutions: Recommendations for future research. Patient Education and Counseling Volume 73, Issue 1 (22 Januari 2020 at 10.49)

Valea, O Popa- dan Purcarea, VL. 2014. Issues of therapeutic communication relevant for improving quality of care. Journal of Medicine and life. US National Library of Medicine National Institute of Health. v.7 (Spec Iss 4) (20 Januari 2020 at 11.34)

Rati, Sanjaya. 2015. Strategi komunikasi terapeutik guru dalam membangun motivasi belajar anak down syndrome. Skripsi. Universitas Multimedia Nusantara (24 Desember 2019 at 10.25 )

Zainun, et all. 2017. The Use of Therapeutic Communication Symbol to Motivate Patient's Healing. IOSR Journal Of Humanities And Social Science (IOSR-JHSS). Islamic University of North Sumatra (UINSU), Medan, Indonesia. Vol. 22, Issue 7, Ver. 6 (20 Januari 2020 at 11.27 ). 